\title{
RAIN WATER RECHARGE TO BEAUTIFY THE GROUND WATER USING GIS
}

\section{RASIKA R WASNIK ${ }^{1} \&$ ASHISH BHAGAT ${ }^{2}$}

${ }^{1}$ Student (Environmental Engineering), Ceinsys Tech Limited/ Dr. S.V. Ambekar, YCCE, Nagpur, India

${ }^{2}$ Research Scientist, Jawaharlal Nehru Medical College, Datta Meghe Institute of Medical Sciences, Sawangi, India

\begin{abstract}
Over-misuse of groundwater and stamped changes in atmosphere throughout the years have forced gigantic weight on the worldwide groundwater assets. As request of consumable water increments over the globe for human utilization, horticulture and modern uses, the need to assess the groundwater potential and efficiency of springs likewise increments $^{1,2,3}$. In the ongoing years, Geographic Information System (GIS) based investigations have increased a lot of unmistakable quality in groundwater investigation since it is fast and will give first - hand data on the asset for additional turns of events ${ }^{4,5}$.

KEYWORDS: groundwater, atmosphere \& GIS
\end{abstract}

Received: Jun 09, 2020; Accepted: Jun 29, 2020; Published: Aug 11, 2020; Paper Id.: IJMPERDJUN2020714

\section{INTRODUCTION}

GIS (Geographic Information Systems) can assist you with distinguishing the water collecting potential and feasibility in a particular zone ${ }^{6}$. All the more explicitly, it can help you with:

- Identifying potential undertaking projects for Rainwater Harvesting.

- Sharing data effectively on the Rainwater Harvesting capability of a particular region by making it visual.

- Making educated choices about time and spending speculations during venture usage.

- Informing contributors, governments and different accomplices about the capability of Rainwater Harvesting.

Rain Water Harvesting is a straightforward strategy of getting and holding water where its falls. Possibly, we can store it in tanks or we can utilize it to enhance groundwater relying on the circumstance.

Features of Rainwater Harvesting are ${ }^{7,8}$ :

- Lessens urban flooding.

- $\quad$ Ease in developing framework in less time.

- Economically less expensive in development contrasted with different sources, for example dams, diversion and so forth.

- Rainwater collecting is the perfect circumstance for those zones where there is deficient groundwater flexibly or surface assets.

- Helps in using the essential wellspring of water and keep the overflow from going into sewer or tempest 
channels, in this way decreasing the heap on treatment plants.

- $\quad$ Recharging water into the springs which help in improving the nature of existing groundwater through dilution.

\section{OBJECTIVE}

The principle target of this exploration paper is to consider the different advances associated with energizing the ground water in a dry district with the assistance of Geographic Information System (GIS).

\section{METHOD}

Different systems have been produced for the choice of appropriate locales and strategies for RWH. Field studies are the most well-known strategy for little territories. The recognizable proof of suitable destinations for the different RWH advances in huge zones is an extraordinary test.The determination rules were characterized both subjectively and quantitatively and depended on a regional investigation utilizing satellite information in blend with hydrological and climatological data ${ }^{9,10}$. The strategy is especially valuable in territories where next to no regional data is accessible, for example, in most creating nations.

The recognizable proof of reasonable destinations for RWH is a significant step towards expanding water accessibility and land efficiency. Incorporated investigations of runoff demonstrating, GISs and RS have effectively focused on locales reasonable for $\mathrm{RWH}^{11,12}$

\section{DATA AND METHODOLOGY}

\section{Land Sat 8 Images}

Satellite pictures were hung over a DEM for 3D territory investigations. Multispectral landsat 8 satellite pictures were utilized to develop the land-spread; standardized deferent vegetation record (NDVI) through the composites of groups. The pictures were corrected utilizing ENVI 5.1 programming

\section{Digital Elevation Model (DEM)}

The advanced height model (DEM) of the region can be extracated from the SRTM (Shutter Radar Topography Mission) information utilizing Envi 5 programming. DEM was utilized to offer varieties of information that aid created landforms map, soil types and hydrology data. Waste systems and sub-catchment limit of the zones can be removed from DEM so as to examine the spatial relationship of horticulture fields and the catchment-waste systems. Digital elevation models (DEMs) are progressively utilized for visual and scientific examination of geology, scenes and landforms, just as demonstrating of surface procedures ${ }^{13,14}$.

\section{Components of Rain Water Harvesting System}

A rainwater harvesting system comprises of components for - transporting rainwater through pipes, filter and recharge well for collection of harvested water ${ }^{15,16}$. The common components of a rainwater harvesting system are:-

- Catchments: The surface which directly receives the rainfall and provides water to the system is called catchment area. It can be a paved area like a terrace or courtyard of a building, or an unpaved area like a lawn or open ground. Coarse Mesh: It prevents the passage of debris, provided in the roof.

- Gutters: Channels which surrounds edge of a sloping roof to collect and transport rainwater to the storage tank. 
Gutters can be semi-circular or rectangular and mostly made locally from plain galvanized iron sheet.

- Conduits: Conduits are pipelines or drains that carry rainwater from the catchment or rooftop area to the harvesting system. Commonly available conduits are made up of material like polyvinyl chloride (PVC) or galvanized iron (GI).

- Filters: The filter is used to remove suspended pollutants from rainwater collected from rooftop water. The Various types of filters generally used for commercial purpose are Charcoal water filter, Sand filters, Horizontal roughing filter and slow sand filter.

- Recharge Structures: Rainwater Harvested can also be used for charging the groundwater aquifers through suitable structures like dug-wells, bore-wells, recharge trenches and recharge pits. Various recharge structures are possible - some which promote the percolation of water through soil strata at shallower depth (e.g., recharge trenches, permeable pavements) whereas others conduct water to greater depths from where it joins the groundwater (e.g. recharge wells). At many locations, existing structures like wells, pits and tanks can be modified as recharge structures, eliminating the need to construct any fresh structures. Some of the few commonly used recharging methods are recharging of dug wells and abandoned tube wells, Settlement tank, Recharging of service tube wells, Recharge pits, Soak ways /Percolation pit, Recharge troughs, Recharge trenches, Modified injection well.

\section{RESULTS}

From the findings we can say that less capital coat is invested to recharge the ground water rather that storing it in the structures like dams, tanks etc.

\section{CONCLUSIONS}

It very well may be closed from the above discoveries that the water, whenever saved and used utilizing precipitation water reaping innovation, can be a compelling device of renewing ground water assets.

\section{REFERENCES}

1. Agarwal A, Mishra D. Evaluation of groundwater potential in the environs of Jhansi city, Uttar Pradesh through hydrogeological assessment by satellite remote sensing technique. J Remote Sensing. 1992; 20:2-13.

2. Agarwal A, Mohan $R$ et al. An integrated approach of remote sensing, GIS and geophysical techniques for hydrological studies in Rajpura block, Budaun district, Uttar Pradesh. Indian J PRVD. 2004: 35-40.

3. Krishnamurthy J, Srinivas G. Role of geological and geomorphological factors in groundwater exploration: a study using IRS LISS data. Int J Remote Sensing. 1995; 16(14):2595-2618.

4. Krishnamurthy J, Mani A et al. Groundwater resources development in hard rock terrain — an approach using remote sensing and GIS techniques. J Applied Geology. 2000; 2(3/4):204-215.

5. Shwetha, G., et al. "Estimation of surface runoff in timmapur watershed using SCS-CN method." Int J AgricSci Res 5.6 (2015): $1-8$.

6. Novaline J, SundaramA et al. Watershed development using geographic information system techniques. Int J Remote Sensing. 1993; 14:3239-3247. 
7. Rao S, Reddy P. Groundwater prospects in a Developing satellite township of Andhra Pradesh, India using remote sensing techniques. J Indian Soc Remote Sensing. 1992; 27(4):193-203.

8. Sankar K. Evaluation of groundwater potential zones using remote sensing data in Upper Vaigai river basin, Tamil Nadu, India. J Indian Soc Remote Sensing. 2002; 30(30):119-129.

9. Saraf A, Choudary P. Integrated remote sensing and GIS for ground water exploration and identification of artificial recharge sites. Int J Remote Sensing. 1998; 19(10):1825-1841.

10. Slimani, R., and A. Guendouz. "Groundwater vulnerability and risk mapping for the Phreatic aquifer in the Ouargla Oasis of Algerian Sahara using GIS and GOD method." International Journal of Agricultural Science and Research (IJASR) 1.5 (2015): 149-158.

11. Sushanth, Kallem, Raj Kumar, and Anil Bhardwaj. "Soil mapping of Patiala-Ki-Rao watershed in Shivalik Foot-Hills using GIS." International J. of Agri. Sci. Res.(IJASR) 9.2 (2019): 1-8.

12. Gupta, K., J. Deelstra, et al. (1997). "Estimation of water harvesting potential for a semiarid area using GIS and remote sensing." IAHS Publications-Series of Proceedings and Reports-Intern Assoc Hydrological Sciences 242: 63.

13. Jankowski, P. Integrating geographical information systems and multiple criteria decisionmaking methods. Classics from IJGIS: twenty years of the International journal of geographical information science and systems. 2006; 9(3): 265.

14. Jasrotia A, Dhiman S et al. Rainfall-runoff and soil erosion modeling using Remote Sensing and GIS technique-a case study of tons watershed. Journal of the Indian Society of Remote Sensing. 2002; 30(3): 167-180.

15. Seckler D, Barker $R$ et al. Water scarcity in the twenty-first century. International Journal of Water Resources Development. 1999; 15(1): 29-42.

16. Rakesh, G., I. Bhaskara Rao, and B. Gowtham Singh. "Effect of Soil and Water Conservation Measures On Ground Water Fluctuations and Recharge on Mutukula Watershed, Prakasam District."International Journal of Agricultural Science and Research (IJASR) 7. 6, Dec 2017, 325-334

17. Bhattarai R, Dutta D. Estimation of soil erosion and sediment yield using GIS at catchment scale. Water Resour Manage. 2007; 21(10):1635-1647.

18. Jain S, Kumar S et al. Estimation of Soil Erosion for a Himalayan Watershed Using GIS Technique, Water ResourManag. $2001 ; 15: 41-54$.

19. Mandal C, Mandal D et al Soil climatic database for a crop planning in India. NBSS Publ. 53 NBSS \& LUP, Nagpur, India. 1999.

20. Ravi Shankar M, Mohan G. A GIS based hydrogeomorphic approach for identification of site-specific artificial-recharge techniques in the Deccan Volcanic Province. J Earth Syst Sci. 2005; 114(5):505-514. 